\title{
Clinical Characteristics of Atrial Fibrillation in Saudi Women Cohort and Its Clinical Impact in a Tertiary University Hospital
}

\author{
Kamal W. AIGhalayini, MD \\ Department of Medicine, Faculty of Medicine \\ King Abdulaziz University, Jeddah, Saudi Arabia
}

\section{Correspondence}

Dr. Kamal W. AlGhalayani

P.O. Box 80215, Jeddah 21589, Saudi Arabia

e.M: kalghalayini@kau.edu.sa

Submission: 2 Feb 2015

Accepted: 2 Mar 2015

\section{Citation}

AIGhalayani KW. Clinical characteristics of atrial fibrillation in Saudi women cohort and its clinical impact in a tertiary university hospital. JKAU Med Sci 2015; 22 (2): 11-17. DOI: 10.4197/ Med. 22.2.2

\begin{abstract}
A retrospective study was conducted to evaluate the characteristics of atrial fibrillation in a cohort of Saudi women, and its impact on morbidity. A complete medical history was obtained and all participants underwent a complete review of clinical data including electrocardiogram, echocardiogram, blood pressure measurement, and thyroid examination. The following laboratory examinations were performed: international normalized ratio; thyroid stimulating hormone; triiodothyronine; thyroxine; total cholesterol; triglyceride; low-density and high-density lipoprotein. A history of hospitalizations, stroke and in-hospital mortality were recorded. We recruited 84 women; the mean age was 61.8 years and the mean body mass index was $28.45 \mathrm{~kg} / \mathrm{m}^{2}$. The mean hemoglobin level of the patients was 12.2 $\mathrm{g} / \mathrm{dL}$ and the mean thyroid stimulating hormone level was $3.75 \mathrm{mlU} / \mathrm{L}$. The target international normalized ratio was achieved in $58 \%$ of treated patients; $70 \%$ of the under target International Normalized Ration patients had been hospitalized more than once and 19\% had suffered a stroke. Overall, international normalized ratio demonstrates gaps in the management of women with atrial fibrillation, and the negative impact on patient outcome, indicating the need to tailor treatment plans to the goals and requirements of these patients.
\end{abstract}

\section{Keywords}

Atrial fibrillation; Diabetes mellitus; Hypertension; Ischemic heart disease; Women

\section{Introduction}

trial fibrillation, the most common supraventricular serious arrhythmia, is well known in the medical community for its most devastating complication: ischemic stroke ${ }^{[1]}$. For this reason, the scientific boards continuously follow the research related progress of the disease and recommend guidelines in order to improve clinical care and outcome $^{[2]}$.

Multiple challenges exist in day to day practice due to the complexity of the disease that makes it difficult to control.

Atrial fibrillation may be classified into paroxysmal, intermittent, persistent and chronic, and the various 
guidelines have directed management into three arms: rate control; rhythm control; and thrombi-embolic prevention. The third arm is paramount in stroke prevention and has a direct link to mortality.

Literature has shown male gender preference in clinical care and presentation for cardiovascular disease ${ }^{[3]}$.

In particular, atrial fibrillation was evaluated in women for this reason: Volgman et al. ${ }^{[3]}$ studied this topic. Women are more affected with atrial fibrillation than men $(60 \%$ in the United States), and add to the worst outcome in terms of mortality and stroke disability. The group studied data from 1989-2009 based on gender difference and concomitant relative factors. Results showed women suffer more symptoms, recurrence and disease behavior such as higher heart rate. The latter related to hormonal variability and its needs include designing the proper treatment strategy $^{[3]}$. Statins were less prescribed for women than men, affecting the proper care of hyperlipidemia as a risk factor in women. Obesity, another risk factor, was observed more in women, and when it comes to Warfarin utilization, it was seen less in women despite the high recommendations for its use. Concerns regarding bleeding tendency mistakenly cause the delay in treatment ${ }^{[3]}$.

Nelson et $a^{\mid 4}$. investigated the cause of poor adherence to anticoagulation (50\%) and the potential results using clinical decision support system to improve this practice. Results implicated causes of physician's non-adherence to clinical guidelines as: Patient preference; relative contraindications; noncompliance; drug availability; and disease uncertainty ${ }^{[4]}$.

In Saudi Arabia, the data on atrial fibrillation is at the development stage, with some registries ongoing in the Arab gulf countries and in Saudi Arabia ${ }^{[4]}$.

Gulf survey of atrial fibrillation events Gulf SAFE was designed with the following three objectives: (a) Arab Gulf clinical characteristics of atrial fibrillation; (b) Evaluating the clinical care and adherence to guidelines; (c) Determining clinical outcome. Results showed an increased number and percentage of women with atrial fibrillation with ischemic heart disease as the major cause in $28 \%$, diabetes mellitus (DM) in 30\%, $16 \%$ with rheumatic heart disease and $19 \%$ with lone atrial fibrillation ${ }^{[5]}$.

In Saudi Arabia, Qanash and Kinsara ${ }^{[6]}$ performed a prospective observational pilot study in King Abdulaziz Medical City in Jeddah, on patients admitted with atrial fibrillation. The results showed co-existing comorbid prevalence averages: hypertension $80.5 \%$; DM $50.45 \%$; and rheumatic origin $9.5 \%$. After applying the CHA2DS2VASc score for thrombo-embolic events, heart failure or ejection fraction $\leq 35 \%$, hypertension, age, diabetes, stroke, TIA or systemic emboli, vascular disease (previous $\mathrm{Ml}$, peripheral arterial disease or aortic plaque) and female sex, patients were classified into groups concerning the co-morbid risk factors with atrial fibrillation: the prevalence of DM $68.8 \%$; hypertension $59.3 \%$; chronic respiratory disease $31.8 \%$; rheumatic valvular heart disease $23.6 \%$; and ischemic heart disease $23.1 \%$.

After reviewing the publications related to the Saudi population and atrial fibrillation, we did not find any publication on evaluation of Saudi women with atrial fibrillation. For this reason, we conducted this study to evaluate the clinical characteristics and outcome of a cohort of Saudi women with atrial fibrillation as a step to improve clinical outcome.

\section{Materials and Methods}

After obtaining the hospital Ethical Committee approval for our research proposal, we conducted a retrospective, cross-sectional, observational study of a cohort of Saudi women with atrial fibrillation at King Abdulaziz University Hospital, Jeddah, Saudi Arabia.

It is the largest academic institute in the western region with a wide capture zone. 197 files were obtained from inpatient and outpatient departments using the hospital information system (HIS) and hard files with diagnosis of atrial fibrillation. Eighty-four files of female patients are included in this study with no exclusion other than male gender.

Three sets of electrocardiograms (ECG) were reviewed to confirm the diagnosis of atrial fibrillation, based on two criteria, irregular ventricular rhythm, and presence of $F$ waves.

All data was collected from hospital files including demographics, co-existing risk factors, diabetes, hypertension, hyperlipidemia and ischemic heart disease, investigations (hemoglobin, thyroid function test (TFT) (TSH, T3and T4), renal function (creatinine) electrolyte Na \& K, liver enzymes ALT, AST). Also included were related medications (warfarin, digoxin, Angiotensin converting enzyme (ACE) inhibitor, Angiotensin receptor blocker (ARB), diuretics, calcium channel blocker and B-blocker) and left ventricular systolic function using ejection fraction (EF) as indicator, 
considering $45 \%$ as a cutoff point below, which function is considered impaired. Stroke diagnosis was reviewed using clinical and radiological computerized tomography (CT) or magnetic resonance imaging (MRI), the number of all cases of re-hospitalization was counted and outcome was measured are, hospitalizations, and stroke for all sample population.

Statistical analyses were performed using SPSS Statistics for Windows, Version 17 (SPSS, Inc., Chicago, IL, USA) with descriptive analyses and variables examined using chi-square $\left(X^{2}\right)$ test. Statistical significance will be defined as $P$ values of less than 0.05 .

\section{Results}

The number of patients included in this study totaled 84. The ages of the patients ranged between 35-85 years old with the mean age at 61.8 years (Table 1 ).

A total of $16(19 \%)$ patients had suffered Ischemic stroke, three of them had a combination of three comorbidities (DM, IHD and hyperlipidemia). Another two patients had a combination of two co-morbidities (DM and IHD). Five patients had IHD alone. Only one patient had a combination of DM and hyperlipidemia. The remaining three patients were not found to have any mentioned co-morbidities.

Computerized tomography (CT) scan results for patients complicated with stroke prove the ischemic rather than hemorrhagic diagnosis.

Three consecutive International Normalized Ration (INR) result on three separate occasions were collected for the total sample of the patients. Mean INR was calculated from the three readings and classified according to therapeutic range of INR in the selected patients: INR level < 2 (Low); INR level 2 or 3 (Normal); INR level > 3 (High).

INR level < 2 (Low) was found in 22 (26\%) patients, INR level 2 or 3 (target) was found in $48(58 \%)$ patients and INR level > 3 (High) was found in $13(16 \%)$ patients.

Body mass index (BMI) was calculated for all patients with a mean of $28.45 \mathrm{~kg} / \mathrm{m}^{2}$. According to the

Table 1. Characteristics and laboratory findings of patients' sample.

\begin{tabular}{|c|c|c|c|}
\hline \multicolumn{2}{|r|}{ Item } & No. of Patients & Percentage \\
\hline \multicolumn{2}{|c|}{ Normal range } & 27 & $33.30 \%$ \\
\hline \multicolumn{2}{|c|}{ Overweight } & 29 & $34.50 \%$ \\
\hline \multicolumn{2}{|c|}{ Obese Class 1} & 15 & $17.90 \%$ \\
\hline \multicolumn{2}{|c|}{ Obese Class 2} & 7 & $8.30 \%$ \\
\hline \multicolumn{2}{|c|}{ Obese Class 3} & 5 & $6.00 \%$ \\
\hline \multicolumn{4}{|c|}{ Hemoglobin } \\
\hline \multicolumn{2}{|c|}{ Normal Range } & 48 & $57.10 \%$ \\
\hline \multicolumn{2}{|c|}{ Anemic } & 36 & $42.90 \%$ \\
\hline \multicolumn{4}{|c|}{ Thyroid Function Test } \\
\hline \multirow[t]{3}{*}{ TS } & Normal Range $(0.4-4.0 \mathrm{mlU} / \mathrm{L})$ & 52 & $61.90 \%$ \\
\hline & Below $0.4 \mathrm{mlU} / \mathrm{L}$ & 7 & $8.30 \%$ \\
\hline & Above $4.0 \mathrm{mlU} / \mathrm{L}$ & 25 & $29.80 \%$ \\
\hline $\mathrm{T}_{3}$ & Normal Range & 57 & $67.90 \%$ \\
\hline $\mathrm{T}_{4}$ & Normal Range & 65 & $77.40 \%$ \\
\hline \multicolumn{4}{|c|}{ Lipid Profile } \\
\hline \multirow[t]{2}{*}{ Creatin } & Normal Level & 72 & $85.70 \%$ \\
\hline & High Level & 8 & $9.50 \%$ \\
\hline \multirow[t]{2}{*}{$\mathrm{Na}$} & Normal Level & 73 & $86.90 \%$ \\
\hline & Low Level & 11 & $13.10 \%$ \\
\hline $\mathrm{K}^{+}$ & Low Level & 70 & $83.30 \%$ \\
\hline \multicolumn{4}{|c|}{ Liver Function Test } \\
\hline \multirow[t]{2}{*}{$\mathrm{AL}$} & Normal & 77 & $91.70 \%$ \\
\hline & High & 5 & $60.00 \%$ \\
\hline AS & Normal & 77 & $95.00 \%$ \\
\hline \multicolumn{4}{|c|}{ Co-morbid Disease } \\
\hline \multicolumn{2}{|c|}{ Diabetes Mellitus } & 50 & $60.70 \%$ \\
\hline \multicolumn{2}{|c|}{ Hypertension } & 30 & $35.70 \%$ \\
\hline \multicolumn{2}{|c|}{ Hyperlipidemia } & 30 & $35.70 \%$ \\
\hline
\end{tabular}


World Health Organization (WHO) classification of BMI, $27(33.3 \%)$ patients were in the normal range of $\mathrm{BMI}$, 29 (34.5\%) patients were categorized as overweight, 15 (17.9\%) patients were categorized as obese class I, 7 (8.3\%) patients were categorized as obese class II, and 5 (6.0\%) patients were categorized as obese class III.

The mean of the hemoglobin level in all patients was $12.2 \mathrm{~g} / \mathrm{dl}$. According to the WHO definition of Anemia in women, 36 (42.9\%) patients were classified as Anemic ( $<12 \mathrm{~g} / \mathrm{dl})$ and $48(57.1 \%)$ patients with $\mathrm{Hbg}$ in the normal range.

Thyroid function test (TFT) was also obtained for the patients. The mean of TSH level for all patients was $3.75 \mathrm{mIU} / \mathrm{L} .52$ (61.9\%) patients had a TSH within normal range $(0.4 \mathrm{mIU} / \mathrm{L} \rightarrow 4.0 \mathrm{mIU} / \mathrm{L})$. Seven $(8.3 \%)$ patients had TSH below $0.4 \mathrm{mIU} / \mathrm{L} .25$ (29.8\%) patients had TSH above $4.0 \mathrm{mIU} / \mathrm{L} .57$ (67.9\%) patients had normal $T_{3}$, and the rest were below the normal. 65 (77.4\%) patients had normal $\mathrm{T}_{4}$, and 4 patients had $\mathrm{T}_{4}$ above normal.

Seventy-two (85.7\%) patients had a normal level of creatinine $(53 \mu \mathrm{mol} / \mathrm{L} \rightarrow 115 \mu \mathrm{mol} / \mathrm{L})$.

Eight (9.5\%) patients had high creatinine levels.

Seventy-three (86.9\%) patients had normal level of $\mathrm{Na}^{+}$compared with 11 (13.1\%) patients with low level of $\mathrm{Na}^{+}$. low.

Seventy (83.3\%) patients had $\mathrm{K}^{+}$level classified as

Regarding liver function test (LFT), ALT level was normal (7 U/L $\rightarrow 56 \mathrm{U} / \mathrm{L})$ in 77 (91.7\%) patients, and was high in five (6\%) patients. AST level was normal (5 $\mathrm{U} / \mathrm{L} \rightarrow 35 \mathrm{U} / \mathrm{L}$ ) in 77 patients (91.7\%), two patients had a high level, and two other patients had a low level of AST.

Fifty-one (60.7\%) patients had DM, 30 (35.7\%) patients had hypertension and 30 (35.7\%) had hyperlipidemia.

Results for medications were: Digoxin 38 (45.2\%); ACE and ARB 48 (57.1\%); B-blocker 49 (58.3\%); CA blocker 22 (26.1\%).

\section{Discussion}

This study revealed a number of factors, which measures in a clinical way the outcomes of a cohort of Saudi women with atrial fibrillation in relation to the natural history of the disease and the medications that had been used as a corner stone for the treatment of those patients.
This current study found a high percentage of risk factors in this population, DM 51\%, hypertension 30\% and high lipid profile 30\%. These figures are higher than once reported by large registries ${ }^{[13]}$, but this may explain the high hospitalization rate, with $70 \%$ having had more than one admission. It may also classify the population in this study as high risk, but at the same time it makes the findings more significant in terms of clinical care as these patients have in fact had more medical attention.

The frequency of rate-control medication results show the difficulty in controlling the rate in female high risk atrial fibrillation patients, as we see more than $39(46.4 \%)$ patients are on two or more rate control medications. This is comparable with results from various papers ${ }^{[14-16]}$.

Anti-coagulation profile INR 2-3 was $58 \%$ in patients with CHA2DS2-VASc score of $>1$; compatible with meta-analysis review of anti-coagulated patients within therapeutic range in the Middle East ${ }^{[17]}$.

This opens an important window for new oral anticoagulant usage to fill the historical gap of undertreated patients; such agents don't require a dose adjustment follow-up and have a safer margin than warfarin.

Wagstaff et al. ${ }^{[18]}$ analyzed data from 17 studies--12 prospective observational studies and five randomized control trials--most of which showed an increased risk of stroke in women of 1.3 fold ( $95 \%$ confidence intervals (Cls) 1.18-1.46) with a marked increase for women with atrial fibrillation aged $>75$ years.

Comparing the full cohort of patients on anticoagulation in three studies showed the rate of stroke for men at $1.2 \%-1.44 \%$ compared to $2.08 \%$ $2.43 \%$ for women, per patient year. However, stroke in women on anticoagulation versus not anti-coagulated seems similar $(95 \% \mathrm{Cl})$ at $1.29(1.09-1.52)$ and 1.49 (1.17-1.90), respectively, indicating that women show an increased risk of stroke that increases with age ${ }^{[18]}$.

The importance of anticoagulation cannot be understated, as shown in many studies, the ability of warfarin use to save up to $26 \%$ of lives and prevent $67 \%$ of strokes in patients with atrial fibrillation, adding to all the risks for women as mentioned ${ }^{[18-21]}$.

Results of blood investigations are of great concern. Although sub-clinical hypothyroidism carries an increased risk of cardiovascular disease ${ }^{[7]}$, we find $43 \%$ of such vulnerable population has high TSH and low T4 compatible with untreated subclinical 
hypothyroidism. And this is comparable to many papers that evaluated endocrine disorders, mainly thyroid disease (hypothyroidism), and its prevalence in patients with cardiovascular disease with a mean coexistence of $36.2-39.8^{[8-10]}$. And the high numbers of hypothyroidism in our collected sample is directly related to the amplitude of this pathology in this part of the world, especially women living in Saudi Arabia $^{[11]}$. It has an indirect indication on the quality of care our patient group is receiving and a major area of improvement that can be provided.

Similarly the results of hemoglobin levels indicate untreated anemia in $43.4 \%$, despite the well-known effect of anemia on cardiovascular disease outcome.

Alquaiz et al. ${ }^{[12]}$ studied the prevalence of anemia and associated factors among women of childbearing age in Riyadh, Saudi Arabia. Of 969 women, the mean hemoglobin in the anemic group and the normal group was $10.81( \pm 1.24)$ and $13.38( \pm 1.31) \mathrm{g} / \mathrm{dL}$, respectively $(P<0.01)$.

They found $40 \%$ (390) of childbearing age women suffered from anemia. These findings are consistent with other local and regional studies, but it is higher than the previous WHO estimates ${ }^{[12]}$.

We have shown in this study of a university tertiary hospital in Saudi Arabia, some important characteristics related to outcome in our patient population and we would like to emphasize the vulnerability of women with atrial fibrillation with the additional risk of increasing age. We have also identified the importance of aiming to close all possible gaps in the clinical care as shown here (anemia and subclinical hypothyroidism).

\section{Conclusion}

The data in this research suggests suboptimal management and care of women diagnosed with atrial fibrillation, which leads to an increase in the risk of morbidity and mortality. We strongly recommend a full evaluation of risk factors, with special attention to the conditions commonly observed in this part of the world. Finally, we advocate a similar work to be done in different regions of the world to relate the common regional conditions to the clinical care of women with atrial fibrillation.

\section{Conflict of Interest}

The author has no conflict of interest.

\section{Disclosure}

The author did not received any type of commercial support either in forms of compensation or financial for this study. The author have no financial interest in any of the products or devices, or drugs mentioned in this article.

\section{Ethical Approval}

Obtained.

\section{References}

[1] Steinberg JS. Atrial fibrillation: an emerging epidemic? Heart 2004; 90(3): 239-240.

[2] Go AS, Hylek EM, Phillips KA, Chang Y, Henault LE, Selby $\mathrm{JV}$, Singer DE. Prevalence of diagnosed atrial fibrillation in adults: national implications for rhythm management and stroke prevention: the Anti coagulation and Risk Factors in Atrial Fibrillation (ATRIA) Study. JAMA 2001; 285(18): 23702375.

[3] Volgman AS, Manankil MF, Mookherjee D, Trohman RG. Women with atrial fibrillation: Greater risk, less attention. Gend Med 2009; 6(3): 419-432.

[4] Nelson WW, Desai S, Damaraju CV, Lu L, Fields LE, Wildgoose $P$, Schein JR. International normalized ratio stabilization in newly initiated warfarin patients with nonvalvular atrial fibrillation. Curr Med Res Opin 2014; 30(12): 2437-2442.

[5] Zubaid M, Rashed WA, Alsheikh-Ali AA, Almahmeed W, Shehab A, Sulaiman K, Al-Zakwani I, Alqudaimi A, Asaad N, Amin H, Gulf Survey of Atrial Fibrillation Events (Gulf SAFE) Investigators. Gulf Survey of Atrial Fibrillation Events (Gulf SAFE): design and baseline characteristics of patients with atrial fibrillation in the Arab Middle East. Circ Cardiovasc Qual Outcomes 2011; 4(4): 477-482.

[6] Qanash SA, Kinsara AJ. Atrial fibrillation in Saudi patients. Ann Saudi Med 2011; 31(3): 318-319.

[7] Danzi S, Klein I. Thyroid hormone and the cardiovascular system. Minerva Endocrinol 2004; 29(3): 139-150.

[8] Tănase DM, lonescu SD, Ouatu A, Ambăruş V, ArsenescuGeorgescu C. Risk assessment in the development of atrial fibrillation at patients with associate thyroid dysfunctions. Rev Med Chir Soc Med Nat lasi 2013; 117(3): 623-629.

[9] Kim EJ, Lyass A, Wang N, Massaro JM, Fox CS, Benjamin EJ, Magnani JW. Relation of hypothyroidism and incident atrial fibrillation (from the Framingham Heart Study). Am Heart J 2014; 167(1): 123-126.

[10] Menezes AR, Lavie CJ, Dinicolantonio JJ, O'Keefe J, Morin DP, Khatib S, Abi-Samra FM, Messerli FH, Milani RV. Cardiometabolic risk factors and atrial fibrillation. Rev Cardiovasc Med 2013; 14(2-4): e73-81. 


\section{Clinical Characteristics of Atrial Fibrillation in Saudi Women Cohort and Its Clinical Impact in a Tertiary University Hospital K.W. AlGhalayani}

[11] Qari F. Hypothyroidism in clinical practice. J Family Med Prim Care 2014; 3(2): 98-101.

[12] Alquaiz AM, Gad Mohamed A, Khoja TA, Alsharif A, Shaikh SA, Al Mane H, Aldiris A, Kazi A, Hammad D. Prevalence of anemia and associated factors in child bearing age women in Riyadh, Saudi Arabia. J Nutr Metab 2013; 2013: 636585.

[13] Alsheikh-Ali AA, Omar MI, Raal FJ, Rashed W, Hamoui O, Kane A, Alami M, Abreu P, Mashhoud WM. Cardiovascular risk factor burden in Africa and the Middle East: the Africa Middle East Cardiovascular Epidemiological (ACE) Study. PLoS One 2014; 9(8): e102830.

[14] Undas A. [Increased thromboembolic risk in atrial fibrillation and stroke prevention in women]. Przegl Lek 2014; 71(3): 164-168.

[15] Klocek M, Skrzek A, Czarnecka D. [Pharmacotherapy of cardiac arrhythmias in women--what do we know, do we have a choice?]. Przegl Lek 2014; 71(3): 155-159.

[16] Janion M, Janion-Sadowska A. [Ventricular and supraventricular arrhythmias in women]. Przegl Lek 2014; 71(3): 142-146.

[17] Zubaid M, Rashed WA, Alsheikh-Ali AA, Al-Zakwani I, AlMahmeed W, Shehab A, Sulaiman K, Qudaimi AA, Asaad N, Amin H; on behalf of the Gulf Survey of Atrial Fibrillation Events (Gulf SAFE) Investigators. Management and one-year outcomes of patients with atrial fibrillation in the Middle East: Gulf Survey of Atrial Fibrillation Events. Angiology 2014: pii: 0003319714536980.

[18] Wagstaff AJ, Overvad TF, Lip GY, Lane DA. Is female sex a risk factor for stroke and thromboembolism in patients with atrial fibrillation? A systematic review and meta-analysis. QJM 2014; 107(12): 955-967.

[19] Sankaranarayanan R, Kirkwood G, Visveswariah R, Fox DJ. How does chronic atrial fibrillation influence mortality in the modern treatment era? Curr Cardiol Rev 2014. [Epub ahead of print].

[20] Kreuzer J. Update on anti-coagulation in atrial fibrillation. QJM 2011; 104(9): 747-760.

[21] Freeman WD, Aguilar MI. Prevention of cardioembolic stroke. Neurotherapeutics 2011; 8(3): 488-502. 


\title{
الخصائص الإكلينيكية للارتجاف القلبي الأذيني وتأثيرها على قطاع من السيدات في المملكة العربية السعودية،دراسة على مرضى مستثفى جامعي
}

\author{
كمال وريب الغلايني \\ قسم الطب الباطني، كلية الطب، جامعة الدلك عبدالعزيز \\ جدة ـ الملكة العربية السعودية
}

المستخلص. دراسة مستقبلية أجريت لتقييم خصائص الإرتجاف القلبي الأذيني عند السيدات السعوديات والتأثنير المنوقع على المر اضه و الوفيات .دون الباحث التاريخ المرضي لكل المرضى كما أجرى لهم الفحص السريري المفصل بالإضافه الإنه إلى تخطيط قلب، تصوير موجات صوتيه للقلب، تسجيل ضغط الدم الثرياني وفحص الغدة الدرقية. التحاليل التي أجريت لكل المرضى في العينة كانت، وظائف غده درقية، كلى وكبد. نسبة الكوليستيرول والدهون الثناثية .أضف إلى ذللك تاريخ

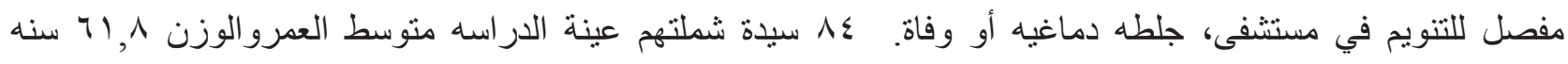

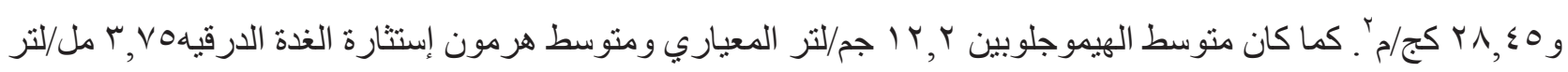

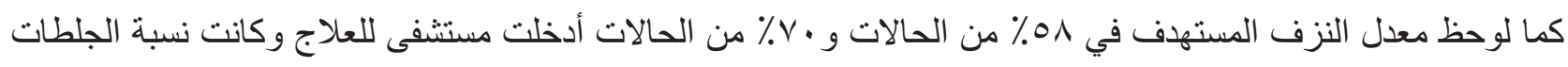
الدماغيه في عموم عينة البحث 9 1\% .دللت الدر اسه عموما على وجود فجو ات في العنايه بالسيدات السعوديات الاتي يعانين من الإرتجاف القلبي الأذيني مما يؤثر سلبا على تطور هذا المرض وزيادة المضاعفات المكن تجنبها، وعليه فإن الباحث يوصي بضرورة إجراء مثل هذه الدراسه على عينه أكبر من المرضى مع إدراج السبل المناسبة لرفع العناية بالسيدات

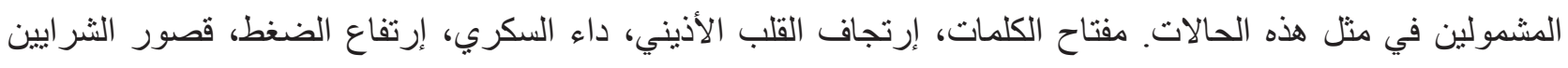
التاجية، النساء. 